\title{
Portable Frost-protection Misting System: Trial on Tomato and Sweet Orange Crops
}

\author{
Lucas McCartney and Mark Lefsrud ${ }^{1}$
}

AdDitional INDEX wORDs. crop freeze, crop growth, latent heat of fusion of water, orchard, Solanum lycopersicum, Citrus sinensis

\begin{abstract}
Summary. During the North American crop-growing season, although daytime temperatures may remain well above freezing point, nighttime temperatures can easily drop below $0{ }^{\circ} \mathrm{C}$ for a few hours. The effects of frost are felt in small operations, such as residential gardens, or in specific areas of a larger operation. Various large-scale measures exist for crop frost protection but they are neither portable nor flexible. A fully automated portable frost-protection misting system that makes use of the latent heat of fusion of water was developed and tested on tomato (Solanum lycopersicum) and sweet orange (Citrus sinensis) at the Macdonald Campus of McGill University (Saint-Anne-de-Bellevue, QC, Canada). The water tank stores up to 20 gal of pressurized water and detachable auxiliary air tanks provide additional line pressure. The device is lightweight, portable and provides flexible, overhead water misting for two 25 - $\mathrm{ft}$ rows of crops. It activates autonomously using a thermostat, battery pack, and solenoid valve, and the outlet pressure is regulated using a pressure regulator. It is easily installed and dismantled for expedient relocation and the dynamic system of tubing and nozzles can be modified as required. The system was tested in subzero ambient air temperature ranging from -7.1 to $0^{\circ} \mathrm{C}$. During misting, the flesh of the targeted tomato fruit remained, on average, 3.1 and $3.6^{\circ} \mathrm{C}$ warmer than ambient temperatures. The use of the system is currently limited by the infrequent formation of ice on the misting nozzles and in the water lines due drastic drops in temperature.
\end{abstract}

$\mathrm{M}$ ost fruit crops grown in northern climates are threatened by frost. Freeze damage represents largest weather related economic loss when compared with all other weather hazards (Snyder, 2000). The importance of frost protection is economically important in the fruitgrowing industry as fruit is of higher value per area than most other common crops. Frost damage occurs when ice forms in and destroys plant tissue. There are two types of frost events: advection frost occurs when colder air flows under warmer air, usually lasting many hours to days, whereas radiation frost (inversion) occurs because of ground heat loss through radiation. Inversion frost is characterized by clear skies, calm winds and temperature inversions and typically lasts a few hours (Perry 1998; Snyder and de Melo-Abreu, 2005). In some cases, a combination of both advective and radiative conditions will

Department of Bioresource Engineering, McGill University, 21111 Lakeshore Road, Ste-Anne-deBellevue, QC H9X 3V9, Canada

The authors gratefully acknowledge support from Mr. Mike Bleho, McGill Macdonald Campus Horticultural Center.

${ }^{1}$ Corresponding author. E-mail: mark.lefsrud@mcgill.ca. occur (Jaradata et al., 2008). A frost event can greatly affect or even destroy flowering and budding of crops in the spring or affect the ripening and harvest of fruit in the fall months. In Spring 2008, Ontario, southern Quebec and northeastern United States fruit growers experienced a series of consecutive cold nights with frost after the blossoming of most species (Environment Canada, 2014). The outcome was a loss of nearly $80 \%$ of the apple (Malus domestica), plum (Prunussp.), pear (Pyrussp.), and sweet cherry (Prunus avium) production in Ontario that year. Most fruit processors saw price increases nearing $50 \%$ (Leung, 2012).

Passive and active measures, or combinations of both can be taken to protect against frost damage. Passive frost protection measures include site selection, use of cold-tolerant cultivars, and delayed planting in the spring. When frost events are inevitable, programs are employed to conserve heat, to add heat, or to circulate air to dissipate temperature inversions. Active methods include crop covers, heaters, wind machines, helicopters, foggers, and irrigation systems (Tyson et al., n.d.). Although effective, active measures require a large amount of supplemental equipment and energy, making them very expensive solutions (Powell and Himelrick, 2000). Some desperate measures such as the use of smudge pots, burning hay bales, spraying liquids with high specific gravity using airblast sprayers, and even covering full orchards with various fabric materials have also been used in North America (Young, 1940). A recent Russian study by Abshaev and Malkarov (2009) looked at the production of artificial smoke layers and fogs. They created a sufficient greenhouse effect by an artificial aerosol layer, containing not less than 1011 aerosol particles/ $\mathrm{m}^{2}$ of $1.5-$ to $2-\mu \mathrm{m}$ size that helps conserve radiation energy losses.

The degree of frost damage is dependent on several factors: the duration of the cold, the growing conditions before the cold event, the cultivar, the stage of development, and critical temperature. Soil type and water content also play a role, as moist dark soil holds more heat than dry light soil (Fisher and Shortt, 2009).

Embryos that do not abort following a frost event may still form misshapen or stunted fruit. Unfortunately, this may not be immediately apparent, and orchard growers continue to incur expenses from pruning and pesticide application only to discover poor quality yields. Even very brief frost events may cause death of

\begin{tabular}{llll}
\hline $\begin{array}{l}\text { Units } \\
\text { To convert U.S. to SI, } \\
\text { multiply by }\end{array}$ & U.S. unit & SI unit & $\begin{array}{l}\text { To convert SI to U.S., } \\
\text { multiply by }\end{array}$ \\
\hline 4.1868 & calorie(s) & $\mathrm{kJ}$ & 0.2388 \\
29.5735 & $\mathrm{fl} \mathrm{oz}$ & $\mathrm{mL}$ & 0.0338 \\
0.3048 & $\mathrm{ft}$ & $\mathrm{m}$ & 3.2808 \\
0.0929 & $\mathrm{ft}^{2}$ & $\mathrm{~m}^{2}$ & 10.7639 \\
3.7854 & $\mathrm{gal}$ & $\mathrm{L}$ & 0.2642 \\
2.54 & inch(es) & $\mathrm{cm}$ & 0.3937 \\
25.4 & inch $(\mathrm{es})$ & $\mathrm{mm}$ & 0.0394 \\
0.4536 & $\mathrm{lb}$ & $\mathrm{kg}$ & 2.2046 \\
1 & micron $(\mathrm{s})$ & $\mu \mathrm{m}$ & 1 \\
6.8948 & $\mathrm{psi}$ & $\mathrm{kPa}$ & 0.1450 \\
$\left({ }^{\circ} \mathrm{F}-32\right) \div 1.8$ & ${ }^{\circ} \mathrm{F}$ & ${ }^{\circ} \mathrm{C}$ & $\left({ }^{\circ} \mathrm{C} \times 1.8\right)+32$ \\
& & & \\
\hline
\end{tabular}

Hortlechnology · June 2015 25(3) 
ovules, as in peach (Prunus persica) and the remaining fruit will most likely develop into a very small fruit called a button, that may persist until harvest (Powell and Himelrick, 2000).

Irrigation techniques have recently been shown to be very effective in the protection of fruit from frost damage. At near freezing or subfreezing temperatures, water sprayed on fruit from water sprinkler systems results in an ice layer that encases the surface of the fruit and protects it from freezing damage (Issa, 2012). Overhead sprinkler irrigation, sometimes called simple overhead irrigation, is done with water lines and nozzles placed in or above the crop canopy. This method has proven effective for low-growing crops such as tomato as well as for vine crops and tree fruit (Bootsma and Brown, 1985).

A permanent system of microsprinklers with a single nozzle placed above each tree, as used in Georgia (Powell and Himelrick, 2000), can be successfully used for frost protection on fruit such as peach. Permanent systems are usually installed where tree-fruit crops are being protected.

Table 1. Typical nighttime energy balance in a citrus orchard during a frost event suggested by Mee and Bartholic (1979).

\begin{tabular}{lc}
\hline Source & $\begin{array}{c}\text { Energy } \\
\left(\mathbf{W} \cdot \mathbf{m}^{-2}\right)^{\mathbf{z}}\end{array}$ \\
\hline Energy from soil & +28 \\
Energy from air & +39 \\
Downward radiation & +230 \\
Upward radiation & -315 \\
Net energy loss & -18 \\
\hline
\end{tabular}

${ }^{2} 1 \mathrm{~W} \cdot \mathrm{m}^{-2}=0.0929 \mathrm{~W} / \mathrm{ft}^{2}$
Growers will install lateral lines down the middle rows and use a galvanized or polyvinyl chloride risers up to $20 \mathrm{ft}$ tall, with the sprinkler mounted on the tip. Considerable installation time and costs are involved.

Sprinklers located under the citrus canopies have been used successfully to prevent freezing damage in Florida, California, Alabama, and Louisiana (Powell and Himelrick, 2000; Wright, 2001). The objective of these systems is to provide nearly full protection in moderate freezes and protection to the trunk and lower scaffolds to allow trees to overcome effects of severe freezes and allow a faster return to production (Powell and Himelrick, 2000)

Heat loss from a plant to the surrounding air and soil can be replaced by the heat released by water changing from a liquid state to a solid state, or simply by the heat energy contained in water that is often slightly warmer than the air. Using an energy balance and considering heat transfer by conduction through an ice layer on the surface of a spherical fruit, the heat transfer of the fruit can be described by the heat transfer due to conduction, evaporation, forced convection, and radiation. Data found in a report by Hasey (1994) suggests that a citrus crop will have a net loss on the order of $18 \mathrm{~W} \cdot \mathrm{m}^{-2}$ of energy on an average radiation frost night (Hasey, 1994). The objective of a frost protection method is to replace the lost energy using, alone or together, enhanced conduction, convection, downward radiation or, in this study, latent heat conversion. When fine water droplets are introduced into the air surrounding the fruit-bearing plants and are condensed and frozen, latent heat stored in the water droplets is converted to sensible heat and slows the temperature drop. The latent heat of fusion of water is $334 \mathrm{~kJ} \cdot \mathrm{kg}^{-1}$ (Haynes and Lide, 2010), or in other terms, when water freezes, it releases 80 calories of heat. This represents $93 \mathrm{~W} \cdot \mathrm{kg}^{-1}$ or $93 \mathrm{~W} \cdot \mathrm{L}^{-1}$ when considered over a 3 -h constant water-freezing event. Because of this warming effect of freezing water, a plant surface such as a leaf will remain $\approx 0{ }^{\circ} \mathrm{C}$ as long as a mixture of water, ice, and water vapor are present, although the temperature of surrounding air may continue to drop. Table 1 , found in a report by Mee and Bartholic (1979), shows heat exchanges that occur in an orchard, including the net loss.

Fruit crops tend to have high sugar contents relative to the rest of the plant, such as stems and leaves, and can therefore withstand cold temperatures for longer periods of time. Each fruit has a critical damage temperature, depending on its sugar content. The crop's critical temperature indicates the temperature at which the frost prevention methods need to be started. Table 2 from Bootsma and Brown (1985) shows various critical temperatures for freeze damage according to the type of crop.

The application of a thin layer of ice on the fruit by a continuous misting of a fine water film prevents the crop from reaching temperatures below $0{ }^{\circ} \mathrm{C}$ (Issa, 2012), keeping the fruit above its critical damage temperature. Once the water application is stopped or the temperature drop becomes severe, the fruit will freeze. It is essential to recognize that this method only prevents the temperature of the protected plant from falling below the freezing point. It does

Table 2. Critical temperatures that result in freeze damage to crops. Examples of crops are given. Data from Bootsma and Brown (1985).

Type

Crop

Critical temp for freeze damage $\left({ }^{\circ} \mathrm{C}\right)^{\mathrm{z}}$

Very tender crops

Strawberry (Fragaria ananassa) and red raspberry (Rubus idaeus) blossom 0 to -1 and fruit, tomato (Solanum lycopersicum), cucumber (Cucumis sativus), melon (Citrullus lanatus and others), pepper (Capsicum sp.), squash (Cucurbita sp.), pumpkin (Cucurbita pepo), beans (Leguminosae), tobacco (Nicotiana tabacum)

Tender crops Potato (Solanum tuberosum), corn (Zea mays), apple (Malus $\times$ domestica)

-1 to -2 blossoms, pear (Pyrus sp.) blossoms and fruit, plum (Prunus sp.) blossom, sweet cherry (Prunus avium) blossom and fruit, beans

Half-hardy crops Apple fruit and buds, blueberry (Vaccinium sp.), alfalfa (Medicago sativa), pear -2 to -4 ${ }^{2}\left(1.8 \times{ }^{\circ} \mathrm{C}\right)+32={ }^{\circ} \mathrm{F}$. 
not warm the plant nor does it raise the air temperature (Bootsma and Brown, 1985).

According to a study by Snyder (2000), starting and stopping sprinklers for frost protection should always occur when the wet-bulb temperature is above the crop's critical damage temperature. Even if the sun is shining on the plants and the air temperature is above $0{ }^{\circ} \mathrm{C}$, sprinklers should not be turned off unless the wet-bulb temperature is above the critical damage temperature. If misting is discontinued prematurely, heat will be drawn from the fruit to melt the ice and freeze damage can result. The same problems arise if the frost lasts too long and the water source runs out. The plants must also be able to support the added weight of ice that builds up on the leaves, fruit, and branches. A forecast of the duration of the frost event is essential (Bootsma and Brown, 1985). In southern Ontario, Canada, protection from freezing temperatures as low as $-6{ }^{\circ} \mathrm{C}$ using irrigation water has been reported by Bootsma and Brown (1985) for lowgrowing berry and vine crops.

Although systems can be permanently installed, the need for cumbersome overhead water lines throughout a crop field or orchard with the required nozzles and line pressure yearround is not always necessary, nor financially available. A portable pressurized misting device can provide convenient water misting onto crop by placing the device outside and securing the misting lines above the crop using existing structures or stakes, only at time periods when needed and in the required areas. Whether freeze prevention methods are economically viable will depend on the crop type and the amount of loss in crop yield or quality resulting from a frost event.

\section{Materials and methods}

The portable frost-protection misting system was designed to be portable and flexible to suit the frost protection needs of small-scale productions or to protect vulnerable sections of large operations otherwise inaccessible by other protection methods. The system's capacity to be enlarged with ease provides additional practicality. The misting system consisted of misting nozzles (10106H; Orbit Irrigation Products, Bountiful, UT) having a $0.012-\mathrm{mm}$ orifice using $0.5 \mathrm{gal} / \mathrm{h}$ at 60 psi. Pressures as low as 30 psi were suitable but lower pressure caused lower radius-of-spray. The majority of testing was done at a 60-psi outlet pressure. The system was also tested at 35 psi, which, according to the manufacturer, should consume roughly $0.2 \mathrm{gal} / \mathrm{h}$ although exact numbers were not available. The water lines were $3 / 8$-inch-diameter tubing made from flexible ultraviolet-treated plastic (Orbit Irrigation Products). They were easily attached using zip ties onto the multiple rod iron sections being used as stakes.

A 20-gal diaphragm water pressure tank (Well-X-Troll; AMTROL, West Warwick, RI) (Fig. 1) was used to store water with a maximum working pressure of 150 psi. The inlet section of the base pipe fitting incorporates a water filter (Orbit Irrigation Products) to ensure minimal dirt and particles enter the tank upon filling to reduce the chances of the nozzles getting clogged during operation. A ball valve allows for filling and shutting-off of this section.

The pressure of the water pressure tank, monitored by pressure gauges (FLOTEC, Delavan, WI), remained between 60 and 80 psi once filled. A pressure regulator ( $1 / 4$ inch national pipe thread female, without gauge, 0 to 125 psi outlet brass; McMaster-Carr, Aurora, $\mathrm{OH}$ ) was used to reduce tank-exit pressure to a 60-psi line pressure (Figs. 2 and 3). During testing, the nozzles functioned well under pressures as low as 30 psi, that introduces the possibility of saving on water usage.

Pressure gauges were installed in two locations on the device, first at the base of the water pressure tank, to monitor filling, and another after the regulator, to allow the user to set the required outlet and line pressure. The gauges allow the user to monitor the system when it is in operation.

A wall mounted thermostat (TL7235Al00; Honeywell, Morristown, NJ) functioned well at low temperatures. The thermostat was used in this device to activate a solenoid valve (12 V direct current; Electric Solenoid Valves, Centereach, NY), turning the system on when the outside temperature reaches $0{ }^{\circ} \mathrm{C}$. If the temperature were to rise above this set point before the tank runs out, the thermostat would then shut the system off. A rechargeable $12-\mathrm{V}$ battery used in remotely controlled systems was installed inside a weatherproof box and was wired through the thermostat and onto the valve.

Two auxiliary air pressure tanks were added to the system to provide extended misting periods and full use of the volume of water in the water pressure tank. The air tanks, pressurized to 100 psi, were connected to the system by quick-disconnect hose couplings (McMaster-Carr) located on the top of the water pressure tank, thus providing additional pressure to above the diaphragm of the water tank. Quick-disconnect hose couplings were also used for attaching the water lines

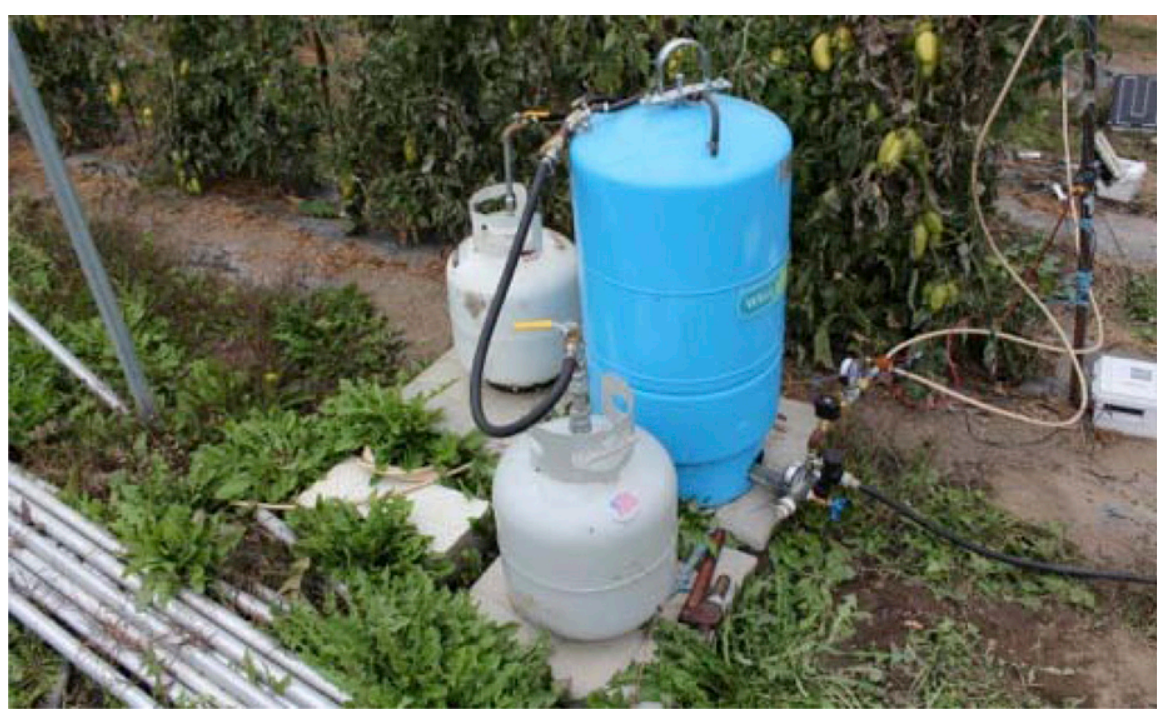

Fig. 1. The portable frost-protection misting system at Macdonald Campus, SaintAnne-de-Bellevue, QC, Canada. Image from Oct. 2013 during a trial on tomato. 


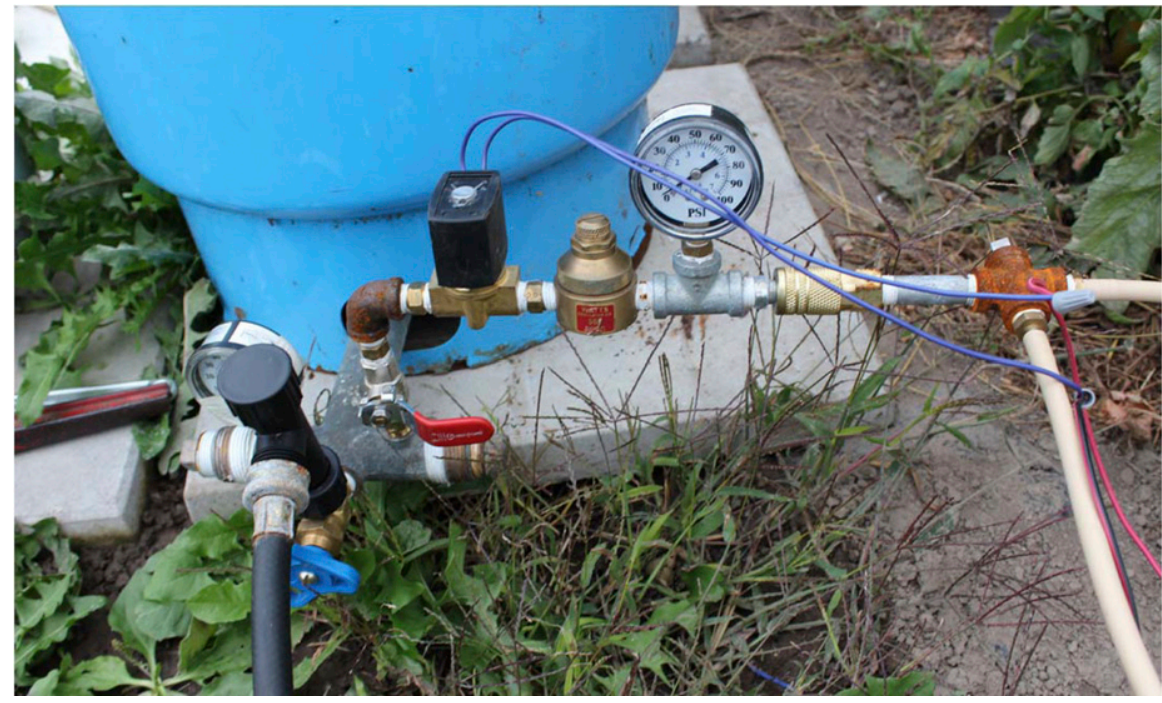

Fig. 2. Appendage devices on the portable frost-protection misting system. Image includes two pressure gauges, two ball valves, solenoid valve, pressure reducer, quick-disconnect hose couplings, $1 / 4$-inch $(6.35 \mathrm{~mm})$ cross section, and a water pressure tank at the Horticultural Center field section B10 at Macdonald Campus, Saint-Anne-de-Bellevue, QC, Canada, during an Oct. 2013 trial on tomato.

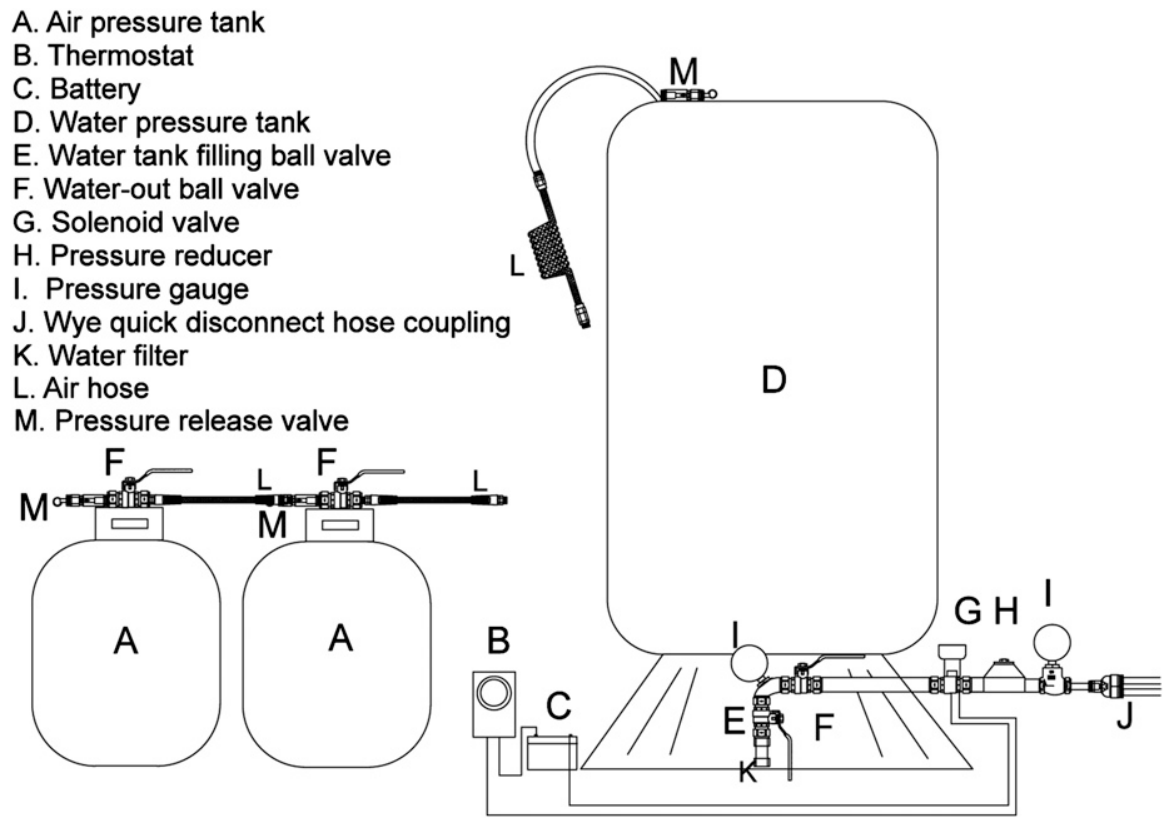

Fig. 3. Schematic of the portable frost-protection misting system apparatus used at the Horticultural Center. Testing at the field section B10 at Macdonald Campus, Saint-Anne-de-Bellevue, QC, Canada, for the Oct. 2013 trial on tomato.

to the device. Modified standard 20-lb domestic propane tanks were used for this purpose, but certified pressure vessels may be used as required by law. A pressure release valve (ExtendLife American Society of Mechanical Engineers Pop-Safety Valve with Test Ring, Brass, Medium Flow, 1/4 inch national pipe thread Male, 150 psi; McMaster-Carr) was also added to this part of the system for safety purposes.
This pressure release valve was set to release at 125 psi.

Full testing of the system and data collection on fruit was performed three times, once on sweet oranges and twice on tomato plants bearing fruit. A data logger (HOBO; Onset Computer Corp., Bourne, MA) with temperature sensors (12-bit temp smart sensor S-TMB-M002; Onset Computer Corp.) was used to collect temperature data. The temperature sensor provides $< \pm 0.2{ }^{\circ} \mathrm{C}$ total accuracy and resolution of $< \pm 0.03{ }^{\circ} \mathrm{C}$ over the range of 0 to $50{ }^{\circ} \mathrm{C}$ with a drift of $<0.1{ }^{\circ} \mathrm{C}$ per year. The full measurement range is -40 to $100^{\circ} \mathrm{C}$. The temperature sensor can be used in air, soil, or water and is designed to last at least 1 year in water as warm as $50{ }^{\circ} \mathrm{C}$ (Onset Computer Corp., 2013). Laboratory calibration of the temperature sensors was accomplished using a large ice bath. Consulted standards recommend using a stable thermal mass of known temperature with a time constant of more than $\mathrm{l} \mathrm{h}$ and designed such that there are no thermal sources or sinks to create local gradients within the mass (American Society of Agricultural and Biological Engineers, 2009).

The first tests were performed on mature 'Paisano' and 'Caiman' with unripe tomato fruit protected under greenhouse tunnels (Fig. 4), during Oct. 2013. Two parallel misting lines $4 \mathrm{ft}$ apart with nozzles located at 2 - $\mathrm{ft}$ intervals along the hoses were placed $3 \mathrm{ft}$ above the crop. One line was placed along the row of crop located closest to the edge of the tunnel and one line was placed along the middle row of crop. Both lines branched out from the device that was placed on the edge of the tunnel greenhouse. The thermostat responsible for starting and stopping the device was placed under the tunnel greenhouse at a height of $3 \mathrm{ft}$ at the start of the edge row. Each misting line covered a $25-\mathrm{ft}$ crop row (Fig. 5).

Five temperature sensors were placed in various locations to allow for the analysis of the conditions when misting was operational. Two sensors were used as temperature references, not under misting conditions. One was placed outside the tunnel and one was placed next to the thermostat on the device. Three sensors were used to detect ambient conditions under the misting lines. Two sensors were pinned to the fruit using thin plastic pins, one on the side row and one on the inside row. The pins were cut pieces of small plastic zip ties that were inserted into the fruit. Another sensor was placed inside a tomato, in a small incision $1 / 8$ inch under the skin of the fruit, on the inside row.

For analysis, temperature data were considered from the time of 
activation of the misting system (when the temperature drops to $0{ }^{\circ} \mathrm{C}$ ) until $0500 \mathrm{HR}$, the approximate time by which the tank would be empty of water. A standard average method was used to compare the data from two outside references to the three sensors under misting conditions.

The second test was done in artificially controlled conditions in a cold room, using sweet orange as test fruit. The entire device, with only four nozzles, along with a metal structure to hold the fruit and water lines in place, was placed inside a cold room. One control sweet orange was used, not under misting conditions, with a sensor pinned to it using plastic pins. Three sweet orange fruit under misting conditions were monitored using sensors inserted in between the peel and the flesh of the fruit after making a small incision in the peel. Lastly, three sensors recorded the ambient temperature at three different levels inside the cold room. The misting system was activated for exactly $2 \mathrm{~h}$ inside the cold room once the temperature dropped below $0{ }^{\circ} \mathrm{C}$.

\section{Results and discussion}

This device is the first of its kind in providing relocatable and flexible irrigation frost protection. A total of 20 nozzles used in the full scale outside tests required a total of $35 \mathrm{~L}$ of water per hour. According to a study done in Ontario, Canada, by Fisher and Shortt (2009) on low-lying strawberry plants, a rate of water application of $0.1 \mathrm{inch} / \mathrm{h}$ is considered adequate to protect to $-4.4{ }^{\circ} \mathrm{C}$ with no wind. When the water is frozen on the plant, the ice should be clear, that indicates there was enough water applied. If the ice is cloudy or milky white, the water application rate is not fast enough to protect the flower (Fisher and Shortt, 2009). The ice in all tests at the Horticultural Center of Macdonald Campus remained clear.

The overall temperature differential between the outside references and the area under misting conditions was of $1.7^{\circ} \mathrm{C}$ for the night of 28 Oct. 2013 and of $1.4^{\circ} \mathrm{C}$ for the night of 29 Oct. 2013 (Table 3 ) when tested on the tomato plants. Both nights experienced temperature inversion events, below the $0{ }^{\circ} \mathrm{C}$ mark. Although ice development was observed everywhere under the misting lines, the thickness

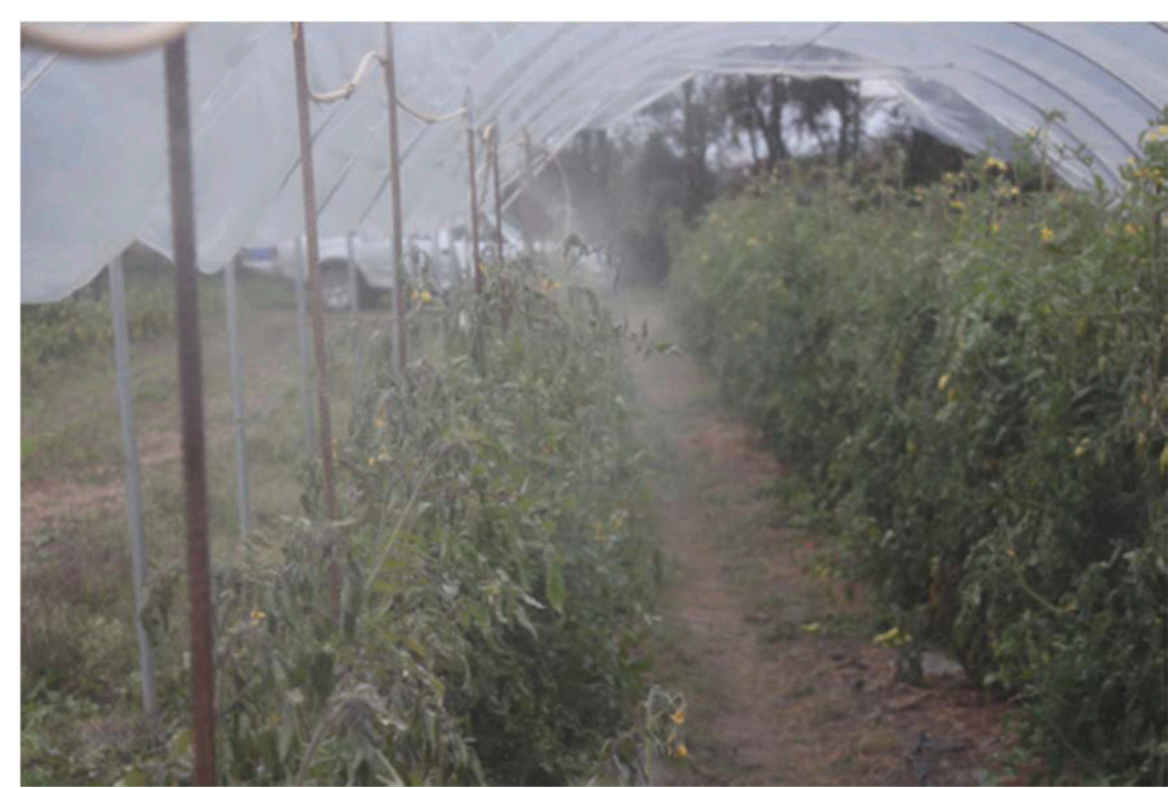

Fig. 4. View of the portable frost-protection misting system in operation. Trial at Macdonald Campus, Saint-Anne-de-Bellevue, QC, Canada, during Oct. 2013 on tomato. One water line is seen with nozzles, attached to the stakes with threads.

varied greatly across the studied crop area.

The overall temperature differential between the ambient environment and the area under misting for the artificially controlled conditions in the cold room was $1.6^{\circ} \mathrm{C}$ (Table 3 ) when tested on sweet oranges. The ice in all tests performed inside the cold room remained clear.

In all experiments, the average temperatures (standard and moving averages) of the flesh of the tomatoes remained warmer and more stable than the temperatures recorded by the sensors pinned to the fruit. This difference between the temperature recorded on the surface of the fruit and the temperature of the flesh was $\geq 3.0^{\circ} \mathrm{C}$ in all cases. The mass of the fruit does conserve some heat as the temperature drops below zero, delaying the freezing of the flesh of the fruit. However, the heat transfer from the ice formation into the fruit stabilized the inner fruit temperature, saving it from eventual freezing. These results are promising as the purpose of this device is to protect the fruit of the plant, and not so much the surrounding environment, leaves, and stems. These experiments showed that this device can provide frost protection to the tomato fruit when surrounding temperatures dropped as low as $-4.0^{\circ} \mathrm{C}$.

As for the test on the sweet oranges, the thick rind of the sweet orange fruit provided additional frost protection so much that the endocarp of the fruit did not experience any variation of temperature when the fruit were submitted to subzero temperatures. According to the U.S. Department of Agriculture, the hardiness of sweet orange trees is classified from -12.2 to $-1.1^{\circ} \mathrm{C}$. With this said, the range of temperatures for ideal winter dormancy for sweet orange trees is from 1.7 to $10.0^{\circ} \mathrm{C}$. Mature, dormant trees have survived $10 \mathrm{~h}$ at temperatures below $-3.9^{\circ} \mathrm{C}$, but fruit is said to be damaged by freezing from -1.1 to $3.3{ }^{\circ} \mathrm{C}$ (Morton, 1987). This makes sweet orange more robust against frost than tomatoes. Nonetheless, according to the data collected and the analysis seen above in Table 3 , some relief from frost up to $1.6^{\circ} \mathrm{C}$ is observed when using this system on sweet orange fruit.

When studying the data from 28 to 29 Oct. 2013 using graphical representations (Figs. 6 and 7 ), it is clear that the recorded temperatures by the sensor located in the flesh of the tomato fruit remained warmer than ambient conditions in all cases. A breakdown of the data to separate fruit surface temperatures from fruit flesh temperatures shows this difference (Table 4). The flesh of the tomato fruit remained at temperatures between 3.1 and $3.6^{\circ} \mathrm{C}$ warmer than the surrounding outside recorded temperatures, whereas the sensors 


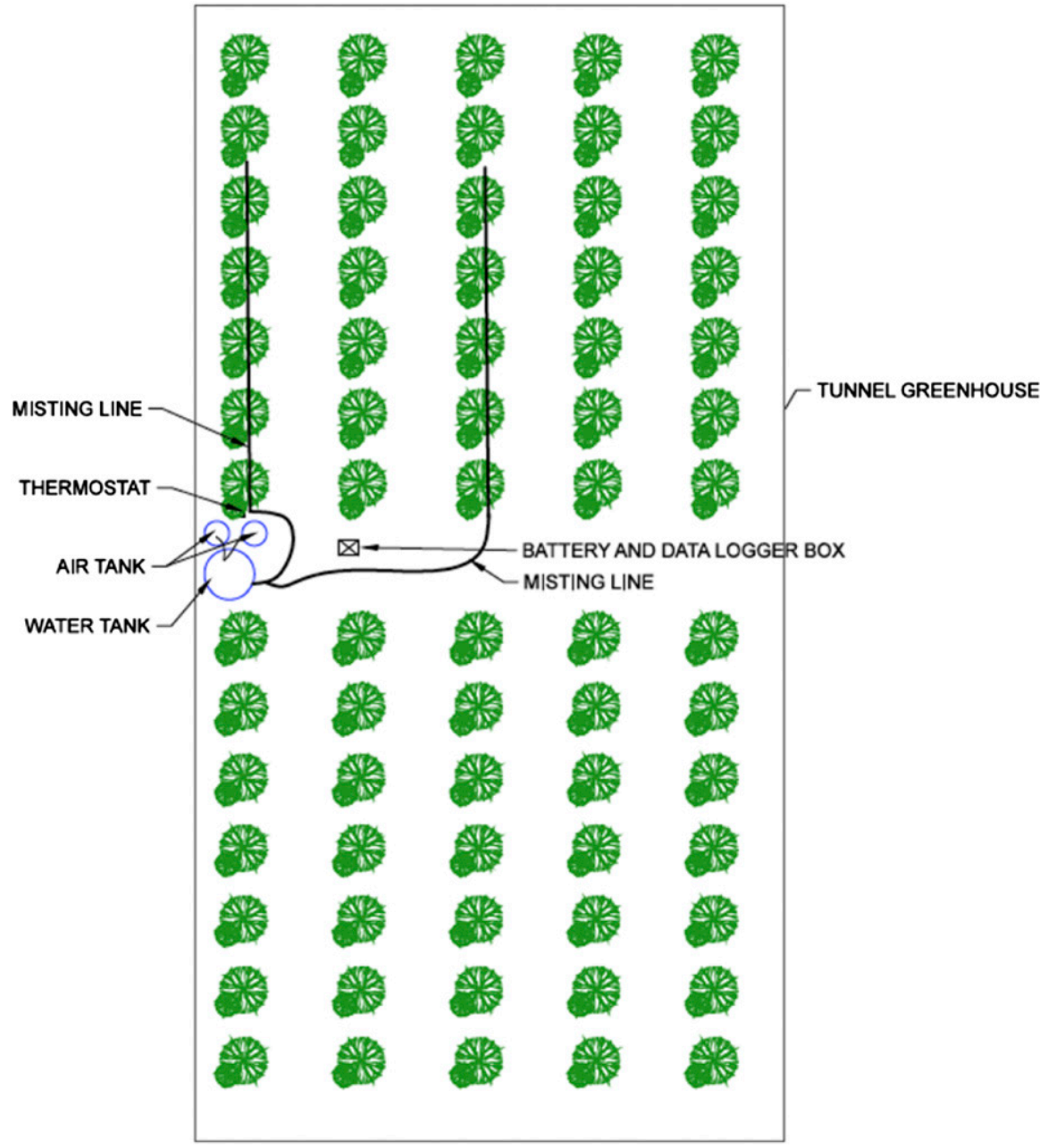

Fig. 5. Overview map of the installation of the portable frost-protection misting system in the tunnel greenhouses. Testing at the Horticultural Center field section B10 of Macdonald Campus, Saint-Anne-de-Bellevue, QC, Canada for the Oct. 2013 trial on tomato.

Table 3. Comparison of recorded temperatures of tomato and orange under misting from the portable frost-protection misting system. Recorded reference temperatures of tomato and orange under unaltered conditions for tests on tomato on 28 Oct. 2013 and 29 Oct. 2014 and a misting test on orange in a cold room at the Macdonald Campus, Saint-Anne-de-Bellevue, QC, Canada.

\begin{tabular}{lccc}
\hline & $\begin{array}{c}\text { Misted } \\
\text { temp }\left({ }^{\circ} \mathbf{C}\right)^{\mathbf{z}}\end{array}$ & $\begin{array}{c}\text { Nonmisted } \\
\text { reference temp }\left({ }^{\circ} \mathbf{C}\right)\end{array}$ & $\begin{array}{c}\text { Difference (inner fruit } \\
\text { to reference temp) }\left({ }^{\circ} \mathbf{C}\right)\end{array}$ \\
\hline $\begin{array}{l}28 \text { Oct. 2014 } \\
\text { Avg }\end{array}$ & -5.4 & -7.1 & 1.7 \\
SD & 0.91 & 1.16 & - \\
29 Oct. 2014 & & & 1.4 \\
Avg & -5.3 & -6.7 & - \\
SD & 0.53 & 0.1 & 1.52 \\
Cold room test & & & 1.56 \\
Avg & -2.86 & -4.38 & \\
Avg & -3.02 & -4.59 & \\
\hline
\end{tabular}

${ }^{z}\left(1.8 \times{ }^{\circ} \mathrm{C}\right)+32={ }^{\circ} \mathrm{F}$.

${ }^{y}$ Data analyzed using a moving average did not differ from unaltered data.

${ }^{x}$ Data analyzed using a moving average method. pinned to the surface of the tomatoes recorded temperatures between 1.4 and $1.7^{\circ} \mathrm{C}$ warmer than the surrounding outside recorded temperatures.

Graphical representations seen in Figures 6 and 7 clearly show how the activation of the misting system helped in conserving heat in the fruit once the temperature was below $0{ }^{\circ} \mathrm{C}$, where a rapid spike can be seen in the recorded temperature inside the fruit.

Overall, the cost of the device was $\$ 590$ (Table 5). Most of the cost was associated with the purchasing of the water tank and required steel fittings. The final cost can vary depending on the total length of misting lines installed and number of auxiliary air tanks used. The water pressure tank and auxiliary air tanks all require transport to a water source and pressurized air source for filling, typically before every use. The front loader of a farm tractor was used in these experiments for transport purposes. An hour at most is required to fill the tanks and install the system in the field. Less than an hour is required to dismantle the system. For practicality, the entire unit is manageable enough to be installed on a standard forklift pallet or on a threepoint-hitch implement platform.

Test 1 from 28 Oct. 2013 was performed with a glycerol additive added to the water in the water pressure tank. Earlier trials revealed that the brass nozzles and plastic water lines were sensitive to certain frost events and easily became clogged with ice. There are several suggested explanations for frozen misting lines and nozzles. A frost event with calm, clear radiative cold spells, low wind speeds, $\left(<0.5 \mathrm{~m} \cdot \mathrm{s}^{-1}\right)$ and high humidity $(>90 \%$ by $0600 \mathrm{HR}$ ) would help keep convective and evaporative heat losses to a minimum, hence reducing ice-clogging of the system. This is not always the case in some locations, such as Florida, when advective frosts with high winds, lower temperatures, and lower humidity are more common. These conditions tend to cause sprinkler freezing (Heinemann et al., 1992). $750 \mathrm{~mL}$ of $99.5 \%$ glycerol was added to the water pressure tank before filling, creating a $0.1 \%$ by volume glycerol content. The glycerol additive helped reduce ice blockage in future trials.

The thermostat used on the device, although functional and sturdy, will require more accuracy given the 


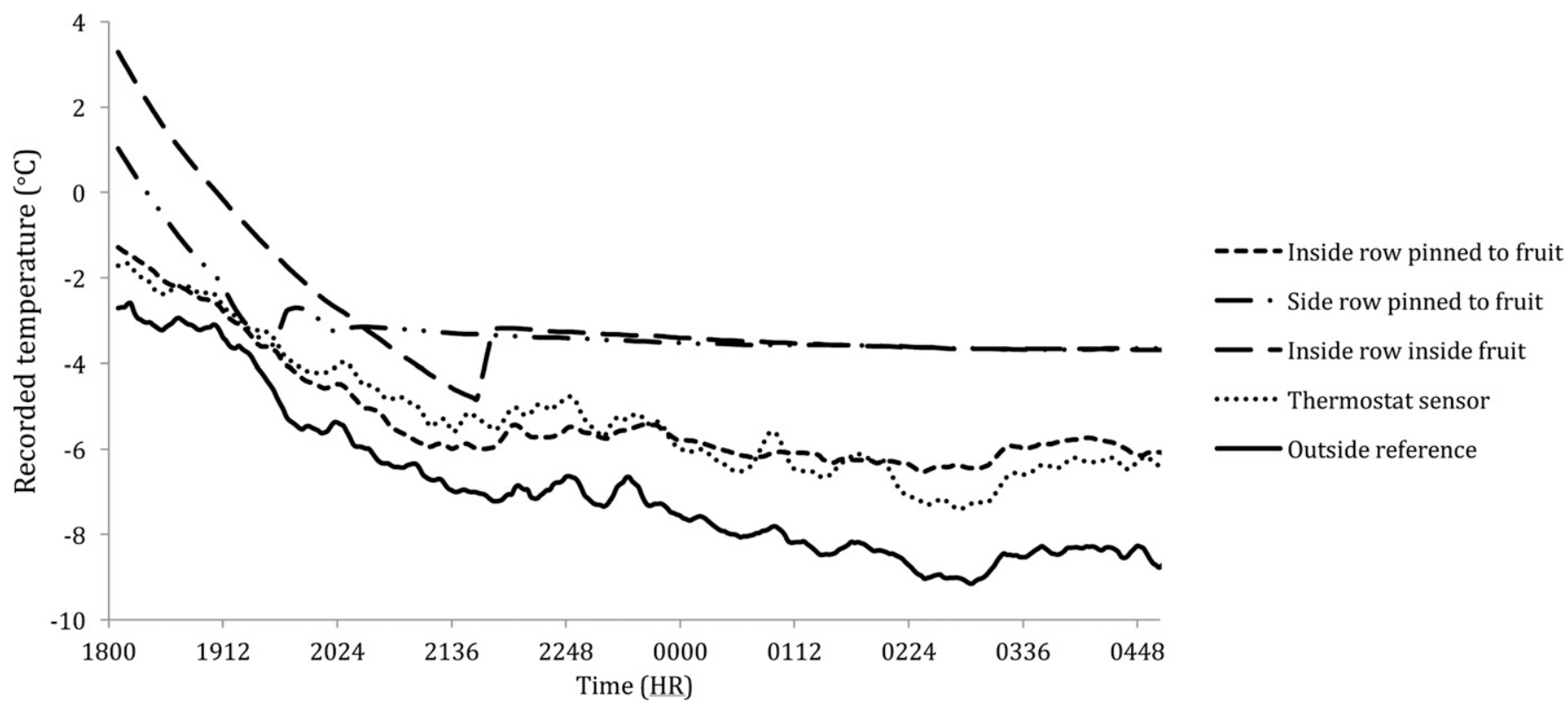

Fig. 6. Graphical representations of the recorded temperatures under the portable frost-protection misting device for the night of 28 Oct. 2013. Testing at the Horticultural Center field section B10 at Macdonald Campus, Saint-Anne-de-Bellevue, QC, Canada, trial on tomato; $\left(1.8 \times{ }^{\circ} \mathrm{C}\right)+32={ }^{\circ} \mathrm{F}$.

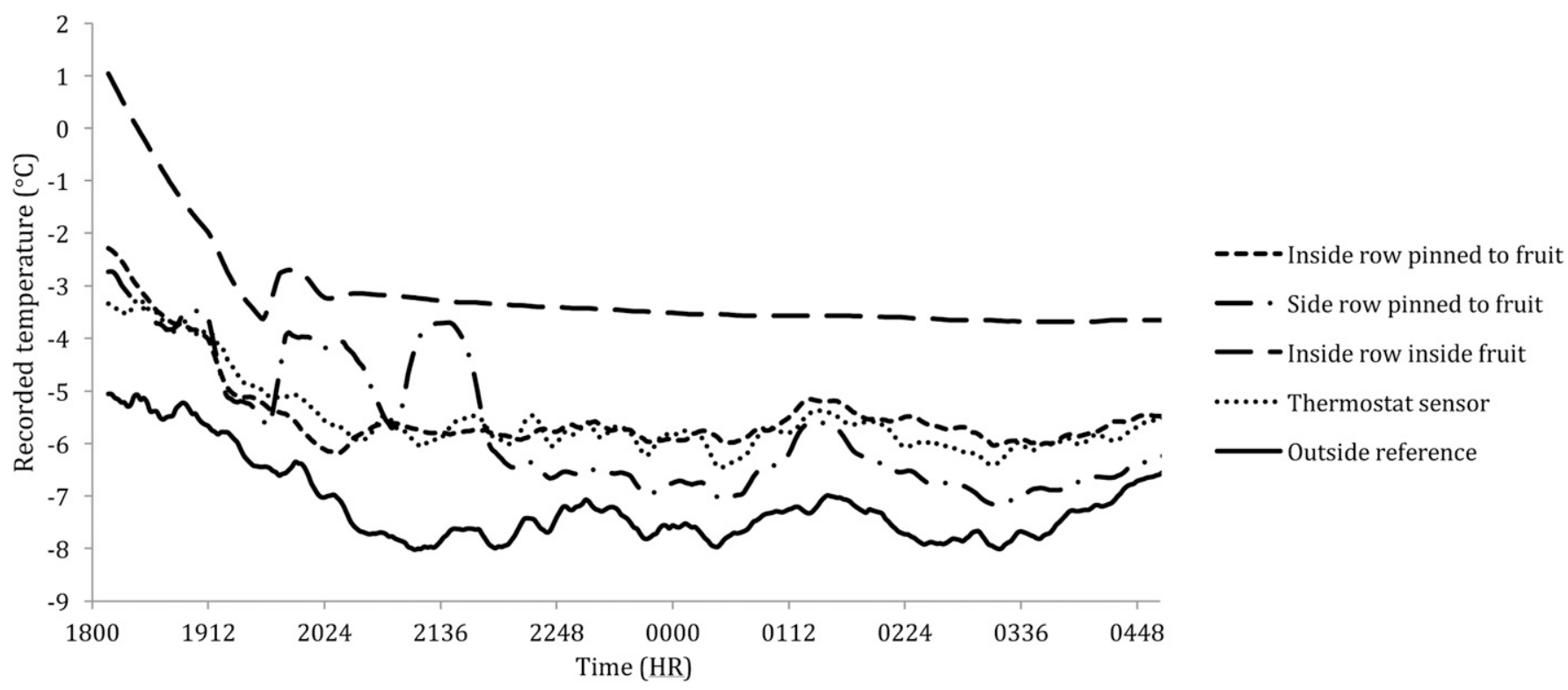

Fig. 7. Graphical representations of the recorded temperatures under the portable frost-protection misting device for the night of 29 Oct. 2013. Testing at the Horticultural Center field section B10 at Macdonald Campus, Saint-Anne-de-Bellevue, QC, Canada, trial on tomato; $\left(1.8 \times{ }^{\circ} \mathrm{C}\right)+32={ }^{\circ} \mathrm{F}$.

small range of temperature $\approx 0{ }^{\circ} \mathrm{C}$ point that is being used to control the system. A digital thermostat with a well-calibrated and well-positioned sensor would ensure instantaneous switching on of the system once the ambient temperature drops to subzero conditions. A thermostat and corresponding sensor are always being protected from direct sunlight or water. Users should give utmost importance to temperature sensor and thermostat placement when installing the device. A thermostat that considers wet-bulb temperatures would provide additional accuracy. These improvements would add a cost to the device.

To predict the overnight wetbulb temperature and starting temperatures for the misting, a technique based on the dew point is used. Table 6 shows the suggested starting temperatures according to research by Fisher and Shortt (2009) done in Ontario, Canada.

The overnight tomato tests were all performed in a tunnel greenhouse, where conditions were slightly different from the actual frost occurrences and outside temperatures experienced in the surrounding fields. When the inversion frost events struck, not all plant sections were affected uniformly because of the tunnel house protection, which 
Table 4. Comparison of tomato fruit surface temperatures to fruit inner temperatures with respect to reference temperatures. Temperatures measured while using the portable frost-protection misting device during frost events on 28 Oct. 2013 and 29 Oct. 2013 at the Macdonald Campus, Saint-Anne-de-Bellevue, QC, Canada.

\begin{tabular}{|c|c|c|c|c|}
\hline & $\begin{array}{c}\text { Misted fruit } \\
\text { temp surface }\left({ }^{\circ} \mathbf{C}\right)^{\mathrm{z}}\end{array}$ & $\begin{array}{c}\text { Misted inner } \\
\text { fruit temp }\left({ }^{\circ} \mathrm{C}\right)\end{array}$ & $\begin{array}{c}\text { Nonmisted } \\
\text { reference temp }\left({ }^{\circ} \mathbf{C}\right)\end{array}$ & $\begin{array}{l}\text { Difference (inner fruit } \\
\text { to reference temp) }\left({ }^{\circ} \mathrm{C}\right)\end{array}$ \\
\hline \multicolumn{5}{|c|}{28 Oct. 2013} \\
\hline Avg & -6.3 & -3.5 & -7.1 & 3.6 \\
\hline $\operatorname{Avg}^{y}$ & -6.3 & -3.5 & -7.1 & 3.6 \\
\hline \multicolumn{5}{|c|}{29 Oct. 2013} \\
\hline Avg & -6.1 & -3.6 & -6.7 & 3.1 \\
\hline
\end{tabular}

${ }^{2}\left(1.8 \times{ }^{\circ} \mathrm{C}\right)+32={ }^{\circ} \mathrm{F}$.

yata analyzed using a moving average did not differ from unaltered data.

Table 5. A detailed cost analysis for the assembling and installation of the portable frost-protection misting device. Cost during construction at the Horticultural Center field section B10 (Macdonald Campus, Saint-Anne-deBellevue, QC, Canada).

Type of cost value

Stainless steel threaded pipe sections, fittings, and valves $\$ 150$

Pneumatic standard quick disconnect hose couplings and fittings

1/4-inch $(6.35 \mathrm{~mm})$ electric solenoid valve

Pressure regulator

$4 \times 10-\mathrm{ft}(3.0 \mathrm{~m})$ Orbit 30060 Arizona Outdoor Misting System

Basic 3/8-inch $(9.525 \mathrm{~mm})$ Cooling Set (Orbit Irrigation Products) 20-Gal (75.7 L) water pressure tank

$2 \times 20-\mathrm{lb}(9.1 \mathrm{~kg})$ propane tanks

$\$ 119$

Battery pack and charger

$\$ 60$

Thermostat

Total

$\$ 20$

$\$ 590$

Table 6. Suggested starting temperatures for misting. Temperatures based on dew point; the lower the dew point, the earlier misting is required. Data modified from Fisher and Shortt (2009).

\begin{tabular}{lc}
\hline Dew point & $\begin{array}{c}\text { Suggested starting } \\
\text { air temp }\left({ }^{\circ} \mathbf{C}\right)^{\mathbf{z}}\end{array}$ \\
\hline-1.1 & 0 \\
-1.7 & 0.5 \\
-2.8 & 1.1 \\
-3.8 & 1.6 \\
-4.4 & 2.7 \\
-5.5 & 3.3 \\
-6.7 & 3.8 \\
-8.3 & 4.4 \\
\hline
\end{tabular}

${ }^{2}\left(1.8 \times{ }^{\circ} \mathrm{C}\right)+32={ }^{\circ} \mathrm{F}$.

created unavoidable variations in the collected data.

\section{Conclusion}

Damage to crops by freezing temperatures causes crop yield losses every year in northern climates. Damage ranges from setback of orchard budding in the spring to loss of tomatoes in the fall. Some of these losses can be prevented using active frost-protection methods. The proposed solution is a portable frost-protection misting system that provides frost protection to tomatoes using a fine mist of water. The fully automated device uses pressurized water and air tanks to provide water misting. The plants growing in tunnel greenhouses were submitted to frost events $\left(<0{ }^{\circ} \mathrm{C}\right.$ and $>-7.1^{\circ} \mathrm{C}$ ) over night late in Fall 2013 in Montreal, QC, Canada. When under water misting conditions, sensors recorded temperatures in the flesh of the tomato fruit between 3.1 and $3.6^{\circ} \mathrm{C}$ warmer than the surrounding outside recorded temperatures. The sensors pinned to the surface of the tomatoes recorded temperatures between 1.4 and $1.7^{\circ} \mathrm{C}$ warmer than the surrounding outside recorded temperatures. The system was also shown to be effective in protecting sweet orange fruit from the onset of frost. The portable frost-protection misting system is effective at providing portable and flexible frost protection to small-scale fruit productions or to vulnerable sections of large operations. The system's capacity to be enlarged with ease provides additional practicality.

\section{Literature cited}

Abshaev, A.M. and K.Z. Malkarov. 2009. Optimization of parameters of an artificial aerosol layer for radiation frost protection. Russ. Meteorol. Hydrol. 34:581589.

American Society of Agricultural and Biological Engineers. 2009. ASAE EP505 APR2004 (R2009). Measurement and reporting practices for automatic agricultural weather stations. Amer. Soc. Agr. Biol. Eng., St. Joseph, MI.

Bootsma, A. and M. Brown. 1985. Freeze Protection Methods for Crops. Ministry of Agriculture, Food and Rural Affairs, Ottawa, ON. 10 Sept. 2014. <http:// www.omafra.gov.on.ca/english/crops/ facts/85-116.htm>.

Environment Canada. 2014. WQB Quebec Jean-Lesage Intl. Historical Climate Data Monthly Data Report for 2012. Climate ID 701S001. 4 Jan. 2015. <http://climate. weather.gc.ca/climateData/dailydata e.html? timeframe $=2 \&$ StationID $=2689 \overline{2}$ \&Year $=2012 \&$ Month $=4 \&$ Day $=1>$.

Fisher, P. and R. Shortt. 2009. Irrigation for Frost Protection of Strawberries. 13 Sept. 2014. <http://www.omafra.gov.on. $\mathrm{ca} /$ english/crops/facts/frosprot_straw. htm>.

Hasey, J.K. 1994. Kiwifruit growing and handling. Univ. California Div. Agr. Natural Resources Publ. 3344.

Haynes, W.M. and D.R. Lide. 2010. CRC handbook of chemistry and physics: A ready-reference book of chemical and physical data. 62nd ed. CRC Press, Boca Raton, FL.

Heinemann, P.H., C.T. Morrow, T.S. Stombaugh, B.L. Goulart, and J. Schlegel. 
1992. Evaluation of an automated irrigation system for frost protection. Amer. Soc. Agr. Eng. 8:779-785.

Issa, R.J. 2012. Numerical heat transfer model for frost protection of citrus fruits by water from a spraying system. Therm Sci. 16:31-42.

Jaradat, M.A.K., M.A. Al-Nimr, and M. N. Alhamad. 2008. Smoke modified environment for crop frost protection: A fuzzy logic approach. Comput. Electron. Agric. 64:104-110.

Leung, W. 2012. Why You'll be Paying More for Produce This Fall. 4 Jan. 2015. $<$ http://www.theglobeandmail.com/ life/food-and-wine/food-trends/whyyoull-be-paying-more-for-produce-thisfall/article $4505943 />$.

Mee, T.R. and J.F. Bartholic. 1979. Manmade fog, p. 334-352. In: B.J. Barfield and J.F. Gerber (eds.). Modification of the aerial environment of plants. Monogr. 2. Amer. Soc. Agr. Eng., St Joseph, MI.
Morton, J.F. 1987. Fruits of warm climates. Echo Point Books Media, Brattleboro, VT.

Onset Computer Corp. 2013. 12-Bit Temperature Smart Sensor (Part No. S-TMB M0XX). 14 Sept. 2013. <http://www. onsetcomp.com/files/manual_pdfs / 7105-I-MAN-S-TMB.pdf>.

Perry, K.B. 1998. Basics of frost and freeze protection for horticultural crops. HortTechnology 8:10-15.

Powell, A.A. and D.G. Himelrick. 2000. Principles of freeze protection for fruit crops. Alabama Coop. Ext. System, Dept. Hort., Auburn Univ., Publ. ANR-1057A.

Snyder, R.L. 2000. Principles of Frost Protection FP005 Quick Answer. 13 Sept. 2013. <http://biomet.ucdavis. edu/frostprotection/Principles $\% 20$ of $\%$ 20Frost\%20Protection/FP005.html>.

Snyder, R.L. and J.P. de Melo-Abreu. 2005. Frost protection: Fundamentals, practice and economics. Vol. 1. Natural Resources Mgt. Environ. Dept., Food Agr. Organization United Nations, Rome, Italy.

Tyson, A.W., R.E. Sneed, C.M. Mainland, K.B. Perry, E.B. Poling, and D.C. Sanders. n.d. Frost/freeze protection by sprinkler irrigation. Univ. Georgia, Southern Reg., Small Fruit Consortium, Athens, GA.

Wright, G.C. 2001. Protecting a citrus tree from cold. Coop. Ext., Univ. Arizona, Publ. AZ1222.

Young, F.D. 1940. Frost and the prevention of frost damage. U.S. Dept. Agr. Farmer's Bul. Publ. 1588. 